\title{
THE ILLEGITIMATE CHILD AND WAR CONDITIONS
}

\author{
EMMA O. LUNDBERG \\ Federal Children's Bureau
}

The year in which was initiated the world war with its overwhelming loss of life, marked also the beginning of a tremendous upheaval of social thought and action, resulting among other things in new conceptions of the meaning and worth of human life. What permanent transformations will come from the war cannot be foreseen. But already there has been a significant readjustment of human values. The balancing of the relation between the State and the individual, the necessity for conservation of the State's human resources, the high evaluation of virile future generations, have become important issues in the midst of the terrible waste of life and health. The State has taken a new interest in all that concerns the physical welfare and biological future of its people, and measures that before the war were left to the haphazard action of private effort have become the accepted duty of the Government.

One of the issues that has gained an accession of interest as a result of war conditions is the problem of illegitimate children. Before the war, this subject had been widely discussed, but with the emphasis most largely on the one of its aspects that concerned the moral and causative side. Since the war the emphasis has shifted to the other phase, more strictly anthropological-the national value of such a child, and the present unfavorable prospects for the proper bringing up of such children. Not because of relative numerical importance, but because of better understanding and greater necessity, have these children of unsanctioned conception received the particular attention of the legislative assemblies of probably most of the countries at war, as a fundamental measure of protection of child life.

Vital statistics in European countries have brought out the fact that a high illegitimacy birth rate not only points to certain social conditions but, most important, that under notions and circumstances such as existed up to the present, means a high infant death rate. Generally the death rate in European countries is reported as more than twice as 
high for illegitimate as for legitimate infants, though they are probably born equally potential as to vitality. Not only have the countries at war taken extraordinary measures to protect these infant lives, but they have greatly extended their efforts to provide for these children a larger measure of normal upbringing and training, taking them under the guardianship of the State for the protection of their future interests.

In regard not only to the situation in connection with the moral side and the question of the prevalence of illegitimacy as a result of warconditions, but also in regard to the action that has been taken in behalf of the children of illegitimate birth, many and conflicting reports have come to us. Official statistics are, unfortunately, lacking to a large extent, especially for the countries about which we hear the most astounding reports from unofficial sources. Often, these statements must be questioned because of their conflict with one another, and the evident absence of any adequate source of information. On the one hand, we have reports of State fostered relaxation of the customs that have promoted family life, and a loosening of the moral ideals that have been a foundation of society. On the other hand, we have accounts of extraordinary concern by the State for the welfare of children who are born into these conditions. From one source we hear of the added emphasis placed on family homes for children, and from another of the taking over altogether of parental obligations and the institutionalizing of children by the guardian State. Where the truth may lie between the conflicting extremes, we can only attempt to gauge by analyzing the somewhat meager data that we are able to secure from official sources, allowing for the abnormal conditions that prevail as a result of war conditions in certain areas to give us the other extreme for which we have no acceptable information.

In order to understand the extent of the problem of illegitimate births and something of its distribution according to racial groups and localities, it is necessary to study the situation as it existed in Europe before the war. The situation after 1914 must be considered to a very large extent as abnormal, and it may be assumed, temporary manifestations of disordered social states. The factors that are at the basis of this problem may, as a result of the war, change radically not only its relative importance, but may also modify still further the treatment that is accorded illegitimate children by the State and by society. Unquestionably, the individual child will become an increasingly important factor, and this consideration is bound to react on the other phases of the problem. Whatever the whole result in the longer run 
will be, one inevitable outcome not only in the countries now at war, but in those at present neutral, will be a squarer facing of the issues involved and definite action by the State toward their solution primarily in the interest of child welfare.

In most European countries vital statistics are, because of their bearing on military service and other governmental requirements, complete and accurate to a degree not attained in the United States except in a few localities. These data on births and deaths are the subject of much research and analysis by governmental authorities and international statistical bodies, and are, therefore, readily available for purposes of comparison. Undoubtedly, differences of method in the various countries must be taken into account, and in some countries there is an absence of figures from any official source, as in Russia, where the records of the Church supply the vital statistics data. In studying comparative figures on the prevalence of illegitimate births it must be borne in mind that in addition to completeness of birth registration, such factors as the legal definitions of illegitimacy enter into the rates, hence the figures are only approximately comparable. Two methods are used for obtaining illegitimacy birth rates. The most common, because it is most readily computed, gives the proportion of illegitimate births to total births, usually stated in terms of number of illegitimate births to a thousand total births. This method, aside from its greater availability, has to commend it the fact that it emphasizes the size of the child care problem involved, and forms a basis for study of comparative death rates of illegitimate and legitimate infants. The second method, generally accepted by European students of the subject as furnishing the more accurate index, is based on a comparison of the number of illegitimate births with the number of unmarried, widowed and divorced women of child-bearing age in the community. This gives data on the prevalence of illegitimate births particularly applicable to the moral side of the question.

The writer has gathered, in Table I, comparative data on the rates of legitimate and illegitimate births based, respectively, on the total number of married women, and the number of unmarried, widowed or divorced women in the various countries. These figures are of interes as showing the trend of the general birth rate over a period of years, the illegitimacy birth rate over the same period, and a comparison of the two. The most striking thing brought out is the regularity of the absolute decline, not only of the legitimate birth rate, but of the illegitimacy rate as well. With the exception of Ireland, all the countries for which we 
TABLe I.

Number of Births in Proportion to the Number of Women from 15 to 49 Years. Annual Average, Infants Born Living ${ }^{1}$

\begin{tabular}{|c|c|c|c|c|c|}
\hline COUNTRIES & $\begin{array}{c}\text { LEGITY- } \\
\text { MATE IN- } \\
\text { FANTS TO } \\
1000 \\
\text { MARRIED } \\
\text { WOMEN, } \\
\text { 15 TO 49 } \\
\text { YEARS }\end{array}$ & \begin{tabular}{|} 
ILLEGITI- \\
MATE \\
INANTS TO \\
1000 UN- \\
MARIIID, \\
WIDOWED, \\
OR \\
DIVORCED \\
(15 TO 49 \\
YEARS)
\end{tabular} & COUNTRIES & $\begin{array}{c}\text { LEGITI- } \\
\text { MATE IN- } \\
\text { FANTS TO } \\
1000 \\
\text { MARRIED } \\
\text { WOMEN, } \\
15 \text { TO 49 } \\
\text { YEARS }\end{array}$ & $\begin{array}{c}\text { HLLEGITI- } \\
\text { MATE } \\
\text { INFANTS TO } \\
\text { 1000 UN- } \\
\text { MARR1ED, } \\
\text { WIDOWED, } \\
\text { OR } \\
\text { DIVORCED } \\
\text { (15 TO 49 } \\
\text { YEARS) }\end{array}$ \\
\hline $\begin{array}{l}\text { Austria-Hungary: } \\
\text { Austria- }\end{array}$ & & & German Empire: & 260 & 28 \\
\hline $1876-1885$ & 246 & 44 & $1886-1895$ & 258 & 28 \\
\hline $1886-1895$ & 250 & 44 & $1896-1905$ & 243 & 26 \\
\hline $1896-1905$ & 242 & 41 & $1907-1914$ & 196 & 23 \\
\hline 1908-1913 & 219 & 30 & Prussia- & & \\
\hline Hungary- & & & $1876-1885$ & 273 & 25 \\
\hline $1876-1885$ & 234 & 41 & $1886-1895$ & 265 & 24 \\
\hline $1886-1895$ & 225 & 49 & $1896-1905$ & 249 & 22 \\
\hline $1896-1905$ & 216 & 41 & $1907-1914$ & 204 & 21 \\
\hline 1906-1915 & 198 & 38 & Bavaria- & & \\
\hline Bosnia and Her- & & & $1876-1885$ & 276 & 42 \\
\hline zegovinia- & & & $1886-1895$ & 263 & 39 \\
\hline $1907-1914$ & 247 & 5 & $1896-1905$ & 259 & 37 \\
\hline Belgium: & & & $1907-1914$ & 214 & 31 \\
\hline $1876-1885$ & 264 & 19 & Saxony- & & \\
\hline $1886-1895$ & 238 & 20 & $1876-1885$ & 267 & 47 \\
\hline $1896-1905$ & 213 & 17 & $1886-1895$ & 250 & 43 \\
\hline $1908-1913$ & 161 & 12 & $1896-1905$ & 216 & 41 \\
\hline Bulgaria: & & & 1907-1914 & 153 & 36 \\
\hline $1896-1905$ & 266 & 2 & Wurtemburg- & & \\
\hline $1910-1911$ & 280 & 4 & $1876-1885$ & 288 & 29 \\
\hline Denmark: & & & $1886-1895$ & 259 & 27 \\
\hline $1875-1884$ & 241 & 26 & $1896-1905$ & 262 & 25 \\
\hline $1885-1894$ & 234 & 24 & $1907-1914$ & 211 & 21 \\
\hline $1896-1905$ & 217 & 23 & Great Britain: & & \\
\hline $1906-1915$ & 191 & 24 & England and & & \\
\hline Finland: & & & Wales- & & \\
\hline $1876-1885$ & 259 & 21 & $1876-1885$ & 250 & 13 \\
\hline $1886-1895$ & 246 & 18 & $1886-1895$ & 228 & 10 \\
\hline $1896-1905$ & 245 & 17 & $1896-1905$ & 203 & 8 \\
\hline $1906-1915$ & 230 & 17 & 1906-1915 & 171 & 7 \\
\hline France: & & & Ireland- & & \\
\hline $1877-1886$ & 166 & 16 & $1876-1885$ & 250 & 4 \\
\hline $1886-1895$ & 149 & 17 & $1886-1895$ & 245 & 4 \\
\hline $1896-1905$ & 134 & 18 & $1896-1905$ & 267 & 4 \\
\hline $1910-1911$ & 114 & 16 & $1909-1912$ & 250 & 4 \\
\hline
\end{tabular}


TABLE I-Continued

\begin{tabular}{|c|c|c|c|c|c|}
\hline COUNTRIES & $\begin{array}{c}\text { LEGITI- } \\
\text { MATE IN- } \\
\text { FANTS TO } \\
\text { I000 } \\
\text { MARRIED } \\
\text { WOMEN, } \\
\text { 15 TO 40 } \\
\text { YEAISS }\end{array}$ & 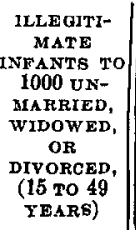 & COUNTRIES & $\begin{array}{c}\text { LEGITY- } \\
\text { MATE IN- } \\
\text { FANTA TO } \\
1000 \\
\text { MARRIED } \\
\text { WOMEN, } \\
15 \text { TO 48 } \\
\text { YEARS }\end{array}$ & 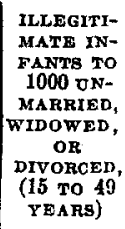 \\
\hline Scotland- & & & Roumania: & & \\
\hline $1876-1885$ & 271 & 20 & $1896-1903$ & 223 & 48 \\
\hline 1886-1895 & 255 & 17 & Russia in Europe: & & \\
\hline 1896-1905 & 232 & 13 & $1896-1897$ & 299 & 17 \\
\hline $1906-1915$ & 202 & 13 & Serbia: & & \\
\hline Italy: & & & $1896-1905$ & 236 & 7 \\
\hline $1877-1886$ & 248 & 24 & Spain: & & \\
\hline $1886-1895$ & 248 & 24 & $1887-1888$ & 230 & 17 \\
\hline $1896-1905$ & 232 & 19 & 1901 & 232 & 14 \\
\hline $1907-1914$ & 226 & 14 & $1906-1915$ & 218 & 14 \\
\hline Netherlands:" & & & Sweden: & & \\
\hline $1875-1884$ & 291 & 9 & $1876-1885$ & 240 & 22 \\
\hline $1885-1894$ & 284 & 9 & $1886-1895$ & 231 & 22 \\
\hline $1895-1904$ & 270 & 6 & $1896-1905$ & 219 & 23 \\
\hline $1905-1914$ & 233 & 5 & $1908-1913$ & 196 & 26 \\
\hline Norway: & & & Switzerland: & & \\
\hline $1881-1885$ & 264 & 19 & $1876-1885$ & 239 & 10 \\
\hline $1886-1895$ & 259 & 17 & $1886-1891$ & 226 & 9 \\
\hline $1896-1905$ & 247 & 16 & $1896-1905$ & 225 & 9 \\
\hline $1907-1914$ & 224 & 13 & $1906-1915$ & 184 & 8 \\
\hline \multicolumn{6}{|l|}{ Portugal: } \\
\hline $1886-1895$ & 235 & 29 & & & \\
\hline $1896-1905$ & 228 & 28 & & & \\
\hline
\end{tabular}

${ }^{1}$ Based upon the Annuaire International de Statistique, publié par L'Office Permanent de l'Institut International de Statisque. Partie II. Mouvement de la population (Europe), pp. 54-56; La Haye, 1917.

${ }^{2}$ The number of women has been calculated.

have figures covering from 30 to 40 years, show a decrease in the number of legitimate births in comparison with the number of married women of the age inclusion. There was a similar decline in the ratio of illegitimate births to the number of unmarried women in all of the countries except France and. Sweden; in the first of these countries the rates were stable, and in the second, there was an increase. During the earliest decennial period for which figures are presented the legitimate birth rate falls in three-fourths of the countries into the 
class interval 231 to 275 births per thousand married women 15 to 49 years of age. During the last time period the rate in three-fifths of the countries falls into the class interval 186 to 230 . The decline in the rate of illegitimate births is less pronounced, yet there also was a consistent shift downward. In the earliest time period, in seventenths of the countries the illegitimacy rate falls into the groups between 10 and 29 births per thousand unmarried, widowed and divorced women; in the last period the rate in seven-tenths of the countries falls between 5 and 24 .

The data presented in Table I suggest the presence of various, causative factors, of anthropological, economical, or social nature. These factors can to some extent be determined by comparative studies of the elements involved. The rates in European countries for the last time period reported, vary from 4 to 38 illegitimate births to a thousand unmarried, widowed and divorced women. These variable illegitimacy rates do not readily lend themselves to explanation on the basis of racial differences nor do they conform with statistical indices of social conditions. Variation is found within groups of the same and apparently homogeneous countries, and in sections of political divisions. Among the contributing factors must be considered the differences in marriage customs and laws, such impediments to marriage as military service, economic conditions, and other restrictions, the density and distribution of the population, the prevailing standards of living, the situation as regards morals, the general attitude toward illegitimacy, and the influence of the Church and other deterrent and constructive forces. All of these elements are closely interrelated. Except for some intensive local investigations in Germany, little has been done in the way of analyses of social causes.

Table II gives the ratios of illegitimate to total births, the so-called "uncorrected rate." As has been pointed out, these figures mainly furnish an indication of the proportion of illegitimate children in the child population, and the problem the State must face in providing for their care and protection. It must be remembered, in attempting to analyze these data that a decline in the total birth rate is likely to result in an apparent rise in the illegitimate birth rate, though in fact the actual number of such births in a year may not have increased. In Great Britain and Bavaria, for example, while the rates indicate an increase, there was an actual decline in the number of illegitimate births. Other countries in which there has been a progressive decrease in the number of illegitimate births annually are Austria, Belgium, France, 
TABLE II

Proportion of Illegitimate Births to All Births in European Countries ${ }^{1}$

\begin{tabular}{|c|c|c|c|c|c|c|c|c|c|c|c|c|}
\hline \multirow{2}{*}{ COUNTRIES } & \multirow{2}{*}{$\begin{array}{c}\text { TOTAL } \\
\text { ILLEGITI- } \\
\text { MATE } \\
\text { BIRTHS } \\
\text { IN } 1914\end{array}$} & \multicolumn{11}{|c|}{$\begin{array}{l}\text { ANNUAL PER CENT ILLEGTTMMATE LIVE BTRTHS IN } \\
\text { TOTAL LIVE BIRTHS }\end{array}$} \\
\hline & & 1906 & 1907 & 1908 & 1909 & 1810 & 1911 & 1912 & 1913 & 1914 & | 1915 & 1016 \\
\hline ustr & & & & & & & & & & & & \\
\hline Aus & $102,845^{8}$ & 12.2 & 12.4 & 12.3 & 12.2 & 12.1 & 11.7 & 11.8 & 11.9 & - - & 一 & - \\
\hline Hun & 63,301 & 9.7 & 9.5 & 9.3 & 9.1 & 9.2 & 9.2 & 9.2 & 9.0 & 8.5 & 9.5 & - \\
\hline $\begin{array}{l}\text { Bosnia a } \\
\text { zogovin }\end{array}$ & 693 & 8.4 & 7.7 & 8.01 & 7.1 & 6.6 & 8.4 & 8.3 & $3 \mid 10.2$ & 9.2 & - & - \\
\hline Belgiun & $10,975^{8}$ & 6.4 & 6.5 & 6.2 & 6.1 & 6.2 & 6.3 & 6.5 & 6.2 & - & - & 一 \\
\hline Bulg & $1,156^{6}$ & 4.5 & 4.7 & 4.9 & 6.0 & 6.4 & $\mid 6.6$ & - & - & - & - & - \\
\hline Denmar & 8,395 & 10.9 & 10.9 & 11.2 & 11.0 & 11.0 & 11.1 & 11.2 & 11.5 & 11.5 & 11.7 & - \\
\hline $\operatorname{In} 1$ ang & 6,846 & 6.8 & 7.0 & 6.9 & 7.0 & 7.4 & 7.4 & 7.8 & 7.8 & 7.8 & 8.0 & - \\
\hline & $64,761^{6}$ & 8.8 & 9.2 & 8.9 & 8.8 & 8.7 & 8.7 & - & - & - & -1 & - \\
\hline Gern & 176,270 & 8.4 & 8.6 & 8.7 & 9.0 & 8.9 & 9.1 & 9.5 & 9.6 & 9.7 & - & - \\
\hline & 25,180 & 12.3 & 12.1 & 12.2 & 12.3 & 12.1 & 12.3 & 12.6 & 12.6 & 12.6 & - & - \\
\hline & 99,172 & 7.2 & 7.4 & 7.5 & 7.7 & 7.8 & 7.8 & 8.2 & 8.3 & 8.5 & - & - \\
\hline & 18,803 & 13.3 & 13.9 & 14.3 & 14.8 & 14.8 & 15,1 & 15.5 & 16.2 & 15.9 & - & - \\
\hline & 737 & 8.3 & 8.9 & 8.4 & 8.2 & 8.3 & 8.4 & 9.1 & 8.8 & 8.5 & - & - \\
\hline Great & & & & & & & & & & & & \\
\hline $\begin{array}{l}\text { Engla } \\
\text { Wa }\end{array}$ & 37,329 & 4.2 & 4.1 & 4.2 & 4.3 & 4.3 & 4.3 & 4.3 & 4.3 & 4.2 & 4.4 & 4.8 \\
\hline Irel & 943 & 2.6 & 2.5 & 2.5 & 2.7 & 2.8 & 2.8 & 2.8 & 2.8 & 3.0 & 3.1 & 3.0 \\
\hline $\mathrm{Sco}$ & 879 & 7.0 & 5.3 & 6.9 & 7.3 & 7.3 & 7.6 & 7.3 & 7.1 & 7.2 & 6.9 & 7.1 \\
\hline taly & 52,813 & 5.3 & 5.2 & 5.0 & 4.9 & 5.0 & 4.9 & 4.8 & 4.7 & 4.7 & - & - \\
\hline & 728 & 2.2 & 2.2 & 2.2 & 2.1 & 2.1 & 2.1 & 2.0 & 2.0 & 2.1 & 2.3 & 2.2 \\
\hline & 4,406 & 6.9 & 6.7 & 6.8 & 6.7 & 6.6 & 6.8 & 6.7 & 7.2 & 7.1 & - & - \\
\hline & $20,601^{5}$ & 11.4 & 11.3 & 11.2 & 11.3 & 11.0 & - & - & - & - & 一 & - \\
\hline & $25,367^{7}$ & 9.6 & 9.0 & 9.2 & 8.6 & 8.7 & 8.4 & 8.1 & - & - & - & - \\
\hline Europe ${ }^{3}$. & $118,159^{4}$ & 2.4 & 2.3 & 2.2 & 2.3 & - & - & 一 & - & 一 & - & - \\
\hline Serbi & $1,581^{5}$ & 11.8 & 12.8 & 12.2 & 14.2 & 14.1 & - & - & - & - & - & - \\
\hline & 28,858 & 4.4 & 4.5 & 4,6 & 4.7 & 4.8 & 4.8 & 4.7 & 4.7 & 4.8 & 5.0 & - \\
\hline & $20,160^{8}$ & 13.0 & 13.1 & 13.4 & 14.0 & 14.3 & 14.8 & 15.3 & 15,4 & -1 & - & - \\
\hline Switzerland. & 4,341 & 4.4 & 4.4 & 4.5 & 4.5 & 4.5 & 4.5 & 4.6 & 4.8 & 4.7 & 5.0 & 4.6 \\
\hline
\end{tabular}

Annual percentage based on statistics of live births reported in the Annuaire Internationale de Statistique, publié par L'Office Permanent de L'Institut International de Statistique, Partie II. Mouvement de la population (Europe), pp. 40-53

2 See Registrar General's report.

${ }^{s}$ Excluding Finland and Poland.

${ }^{4} 1909$.

ธ 1910.

${ }^{6} 1911$.

71912.

81913 . 
Great Britain, Italy, Norway, and the Netherlands. Increases in the annual number of illegitimate births during a thirty to forty year period have occurred in the German Empire as a whole, especially in Prussia, and in Bulgaria, Denmark, Finland, Bosnia and Herzogovinia, Hungary, Portugal, Roumania, Russia in Europe, Serbia, Sweden, and Switzerland It is to its aspects as a problem of child care and dependency, and the seriousness of the mortality rate of illegitimate infants, that the European countries are turning in their interest in illegitimacy as a social issue of the greatest concern at the present time.

In the social changes that came when Europe was plunged into war, old customs were uprooted, the existing order was disturbed, and revolt against conservative ideals seemed likely to alter the standards that society had sanctioned. The economic and social relations of the sexes were altered; artificial distribution of population resulted from concentration of men in army camps; emotional disturbance was a part of the war excitement; the growing independence of women, economically and socially, forecast freedom from restraints. On the other hand, the added responsibilities and the seriousness of the times, the greater individual freedom of women, and the general absence of leisure time, might be presumed to have counteracted these conditions to a considerable extent. Also, we must take into account the increased number of marriages early in the war, and the large proportion of the men removed to the front.

In England the Registrar-General has called attention to the fact that the war has produced no perceptible effect on the statistics of illegitimate births, in spite of predictions current in the early months of the war. The following figures for Great Britain and Ireland are from the annual reports of the Registrar-General.

Number of Illegitimate Births and Percentages to Total Births, $1913-1916^{1}$

\begin{tabular}{|c|c|c|c|c|c|c|}
\hline \multirow[b]{2}{*}{ YEAR } & \multicolumn{2}{|c|}{ ENGLAND AND WALES } & \multicolumn{2}{|c|}{ SCOTLAND } & \multicolumn{2}{|c|}{ IRELAND } \\
\hline & $\begin{array}{c}\text { Total } \\
\text { illegitimate } \\
\text { b1rths }\end{array}$ & $\begin{array}{l}\text { Per cent of } \\
\text { total births }\end{array}$ & $\begin{array}{c}\text { Total } \\
\text { illegitimate } \\
\text { births }\end{array}$ & $\begin{array}{l}\text { Per cent of } \\
\text { total births }\end{array}$ & $\begin{array}{c}\text { Total } \\
\text { illegitimate } \\
\text { births }\end{array}$ & $\begin{array}{l}\text { Per cent of } \\
\text { total births }\end{array}$ \\
\hline 1913 & 37,909 & 4.3 & 8,548 & 7.1 & 2,821 & 2.8 \\
\hline 1914 & 37,329 & 4.2 & 8,879 & 7.2 & 2,943 & 3.0 \\
\hline 1915 & 36,245 & 4.4 & 7,875 & 6.9 & 2,953 & 3.1 \\
\hline 1916 & 37,689 & 4.8 & 7,783 & 7.1 & 2,718 & 3.0 \\
\hline
\end{tabular}

1 Vital Statistics as Affected by the War. By Mallett (Sir Bernard), Presidential Address, J. Roy. Statist. Soc., 1918, LxxxI, Part I. 
In 1915 , the first year in which war conditions could have affected the illegitimacy birth rate, the total illegitimate births in England and Wales decreased 3 per cent. In 1916 there was an increase of 1 per cent over 1914. In Scotland the number of illegitimate births in 1915 was 11.3 per cent, and in $1916,12.3$ per cent lower than the rate in 1914. In Ireland there was an increase of .3 per cent in 1915, and in 1916 a decrease of 7.7 per cent over the numberfor the year preeeding the war. The ratios of per cent of total births are practically even, the only appreciable rise being in England and Wales for the year 1916. Taking the corrected rate ${ }^{1}$ based on the number of illegitimate births in proportion to the unmarried and widowed female population 15 to 45 years of age, the rates for England and Wales were 7.9 in 1913; 7.7 in $1914 ; 7.4$ in $1915 ; 7.6$ in 1916 . By this more accurate method it appears that there was an actual decline in the years following the outbreak of the war.

For Germany we have available no official figures on the birth and death rates after 1914. A secondary source, a bulletin published in Denmark in March, 1917, ${ }^{2}$ furnishes data on the comparative birth rates in Germany in 1913, 1914, 1915, and 1916, but the figures are derived by estimating the total number of births in the Empire on the basis of statistics from places with more than 15,000 inhabitants, and the kingdom of Saxony. By this method, the statement is made that the total number of births in Germany in 1915 decreased 23 per cent as compared with 1913, and in 1916 decreased 40 per cent on 1913.

It will be seen by Table II that the total illegitimate births in the German Empire in 1914 were 176,270. From 1906 to 1914 the proportion of illegitimate to total births averaged 9 per cent. Figuring the same rate of decrease for illegitimate as for legitimate births, if this percentage had been maintained in the years of the war, the total illegitimate births in 1915 would have been about 130,000, and in 1916, about 100,000 . What the actual figures are probably is not known except to official Germany itself. That there has been an increase of considerable proportions is the testimony of various writers with more or less first-hand information. Some of the figures that we see quoted in regard to the number of illegitimate births in Germany since the beginning of the war overreach the probable total of all births, in con-

${ }^{1}$ Mallet, B., o. c.

${ }^{2}$ Bulletin der Studiengesellschaft für Seriale Folgen des Krieges. No. 3. Die Bevölkerungsbewegung im Weltkrieg. Copenhagen, March 15, 1917. 
sideration of the total number of women of child-bearing ages in the Empire.

We have, however, statistics for Berlin, the following table being adapted from data given in the October, 1916, issue of the Jahrbücher für Nationaloekonomie und Statistik. ${ }^{3}$ The rate of illegitimate births in Berlin has consistently been about two and one-half times as high as the rate for the German Empire, ranging for the past few years from 20 to 24 per cent of the total births in the city. According to the figures quoted, the first year in which there might have been an increment of births as a result of war conditions showed a decrease of 18.9 per cent in the number of illegitimate births as compared with the

TABLE III

Percentage of Illegitimate Births in Total Live Births in Berlin During Specified Periods

\begin{tabular}{|c|c|c|c|c|c|}
\hline \multirow{3}{*}{\multicolumn{3}{|c|}{ PERIOD }} & \multicolumn{3}{|c|}{ LIVE BIRTHE IN BERLIN } \\
\hline & & & \multirow{2}{*}{ Total } & \multicolumn{2}{|c|}{ Illegitimate } \\
\hline & & & & Number & Per cent \\
\hline \multirow{3}{*}{ The year: } & $\int 1913$. & & 40,833 & 9,507 & 23.3 \\
\hline & $1914 \ldots$ & & 37,493 & 8,473 & 22.6 \\
\hline & 1915. & & 30,993 & 6,870 & 22.2 \\
\hline \multirow{4}{*}{\multicolumn{2}{|c|}{ Six months, January-May }} & $(1913 \ldots \ldots \ldots$ & 17,764 & 4,216 & 23.7 \\
\hline & & $1914 \ldots$ & 16,212 & 3,990 & 24.6 \\
\hline & & 1915. & 15,031 & 3,430 & 22.8 \\
\hline & & $1916 \ldots$ & 10,176 & 2,419 & 23.8 \\
\hline
\end{tabular}

preceding year, and a decrease of 26.8 per cent as compared with the year 1913 when entirely normal conditions might be assumed to have prevailed. If these figures are reliable, they indicate a greater rate of decrease in the number of illegitimate births than in the total number of births, the decrease for which is given as 17.3 per cent in 1915 over 1914 , and 24 per cent over 1913 . It will be seen that the rate of illegitimate to total births remained practically constant. The rates based on figures for six-month periods may point to a slight increase in 1916, but as shown by the figures for the half-year and year periods for 1914, it is evident that this is not a reliable index for the year.

${ }^{3}$ Article on Infant Mortality, Birth Rate and General Mortality Rate in Berlin during the War, 548-554. 
The only other warring country for which we have any data for a period affected by the war is Hungary. Here the illegitimate birth rate in 1915 showed an increase of 1 per cent over that of 1914 , although the increase over the preceding years was very slight. The rates for Hungary over a period of yearshave been practically the same as for the German Empire. For Austria, the rates have been from 2 to 3 per cent higher.

The changed conditions resulting from the war might be expected to have affected the situation not only in countries actively engaged in the war, but also in the neutral European countries. The data contained in Table II do not, however, point to any appreciable change in the percentages of illegitimate to total births in the countries for which we have figures. In Denmark, Finland, the Netherlands, Spain and Switzerland, we find the rates for 1915 practically the same as for the preceding years. Insofar as we have figures based on the proportion of illegitimate births to the total number of unmarried, widowed and divorced women, the rates have continued to decline.

On the other side of the question-the status and care of illegitimate children-we have positive evidence. Changes have proceeded along three lines: (1) Improvement in legal status, making the process of determining paternity more easy and available; changes in methods of legitimation; removal of the illegitimacy record from birth certificates; and placing illegitimate children on an equality with legitimate children as to government allowances and support. (2) Provision of facilities for maternity care, and for care of children; establishment of orphanges, and extension of placing dependent children in family homes. (3) Recognition of public responsibility for the welfare of all children.

In Germany, on the very day war was declared, provision was made for separate allowances for the support of the dependents of soldiers. This law did not, however, include illegitimate children, but the Government soon made a special arrangement for extending the allowances to them provided the responsibility of the father for their maintenance had been legally established. In order to provide against the difficulty of securing documentary evidence, preventing many children from securing the allowances, the strict and legal formalities previously required were abrogated. In Austria-Hungary and in England, similar separate allowances have been granted, and provision made for pensions to be paid to illegitimate as well as legitimate children. Marriage by proxy has been instituted in France and Italy, largely for the 
purpose of legitimating children, thus providing for their support. In 1917 Russia extended separation allowances to illegitimate families providing that the soldier makes a written application to that effect. Germany has gone farther than any other country in removing the stigma from the record of the illegitimate mothers and their children. During the winter of 1916, the German State Governments with the exception of Prussia, abolished the illegitimate birth certificate. In March, 1918, the Prussian Minister of the Interior stated that he had ordered a new form of birth certificates on which no reference should be made to the parents. This was done out of regard for the illegitimate children.

In England, as in Germany, war conditions have focused attention on the need for the prevention of infant deaths, and the abnormally high death rate among illegitimate infants. Special measures have been taken for assisting unmarried pregnant women. Maternity care has been provided and maternity benefits extended to include these mothers. Public and private agencies have done much in assisting unmarried mothers to keep their children and care for them properly. In Austria, special provision is made for support of the mother during confinement and for a period following the birth of the child.

In Germany, long before the war, illegitimate children were the subjects of special guardianship by the State. The war showed the need for more comprehensive measures for their protection. Most of the States had laws providing for some form of guardianship over illegitimate children. The application of these measures was left to individual towns and local authorities. In Leipzig and some other cities, a scheme was instituted under which doctors and nurses were appointed to look after all illegitimate children. In Berlin the official guardians arrange with the infant welfare centers to supervise infants coming under their care. The Public Guardians of Berlin had under their care in 1912, nearly 5,000 illegitimate children, one of their special functions being to secure maintenance for them from their fathers. In Mannhein the municipal authorities in 1913 undertook complete supervision over all illegitimate children, extending to them also medical and nursing care. During the war, the various forms of guardianship have been exercised with greater care than formerly. In Breslau it was decided, early in 1917, to give allowances from municipal funds to unmarried mothers who wish to bring up their children themselves. These mothers may be assisted in learning a trade. 
In Austria an Imperial Order ${ }^{4}$ was issued in October, 1914 providing for the administration of guardianship over dependent children, and establishing the office of Chief Guardian. The guardianship was placed in the hands of individuals, child-caring agencies, or public bodies, each community determining the kinds of cases to which guardianship should apply, and working in coöperation with the local guardianship court. It is especially provided that the Chief Guardian may assume permanently the guardianship of all or certain groups of illegitimate children in the district who have no legal representative. He may be charged with certain specific rights and duties, such as supervision of the child, collection of money paid for the child's support, and similar duties of a legal representative. The birth of an illegitimate child must be reported by the midwife to the Chief Guardian. The children under supervision must be examined by a physician from time to time, and the manner of bringing up and caring for them regularly investigated.

In July, 1917, two very similar pieces of social legislation were passed in France and in Italy. By these "War Orphan Laws," these countries received the children who had become dependent as a result of the war, into the guardianship and protection of the State. The French and Italian laws follow, in general, similar lines of organization and they have the same purpose in view. Aid is extended not only to children orphaned by the war, butalso to those whose father or mother has been incapacitated from earning a livelihood as a result of the war.

Under the French law, no distinction is made as to the legitimacy of birth. In the Italian law, illegitimate children are specifically included under the provisions for State aid and protection, provided their paternity has been established.

According to the French law,

"When the father or person providing support of the ward is dead or reduced to total incapacity for earning a livelihood, the Nation assumes the partial or total charge of the material upbringing and of the education necessary to the normal development of the ward, in case the resources of the family are insufficient."

There is created in Paris, a "National Office of the Wards of the Nation." At the headquarters of each department there is established a "Departmental Office of the Wards of the Nation," under the general supervision of the National Office. The duties of the Departmental

4 Sec. 208 of General Civil Code. 
offices are: To scrutinize the laws protecting childhood; to place in families or foundations, or in public or private educational establishments, the wards whose guardianship or provisional care is confided to their office, or whose parents or guardians solicit intervention; to inspect and supervise institutions and organizations. Cantonal sections are created to assist the Departmental offices in carrying out the intent of the law. The benefits of the law are extended to the children of French subjects and Colonials, and to those of foreigners serving in the French armies.

In both France and Italy the immediate step for consideration of measures to be taken for the child's welfare is the formation of a "family council," and the nomination of a guardian. Assistance is to be rendered preferably leaving the child in his own family or with his guardian, though provision is made for placing orphans in charge of institutions or organizations standardized and inspected by the State.

The rate of illegitimate births in the United States, insofar as we can assume that the sections for which adequate data are available are representative, is considerably lower than that in most European countries. Inadequacy of birth registration in this country makes it impossible to make proper comparisons, but apparently the usual proportion of illegitimate births to total births is from 3 to 4 per cent. Within the past few years the whole question of illegitimate births has received a great deal of attention, though generally at the hands of private organizations rather than as a State problem. Very little advance has been made in legislation pertaining to the status and support of the illegitimate child. With increased recognition of the meaning of the problem, and with the impetus that the war has given to all efforts toward conserving child life, many beneficial changes in this respect will doubtless come in the United States as in European countries. In the Federal law providing for allotments and granting allowances to the dependents of soldiers, governmental recognition was given to the equal needs of all children for proper support. Here illegitimate children were placed on the same basis with legitimate children as being entitled to support by the father and by the Government. Whether or not conditions that have come since the United States entered the war, will affect the illegitimate birth rate, it is too early to determine. Regardless of whether the numbers are increased or decreased, it cannot be doubted that these children, who from the anthropological point of view are in no way inferior, but who by the conditions of their birth are in special need of protection, will, as a result of the war, become in a larger measure the special concern of the State. 